ISSN $1412-2936$

\title{
Analisa Penentuan Tarif Jasa Rawat Inap dengan Menggunakan Activity Based Costing System (ABCS) di Rumah Sakit Paru Pamekasan
}

\author{
Nuzulul Qurnain \\ Universitas Madura
}

\begin{abstract}
Abstrak
Activity Based Costing System (ABCS) merupakan suatu sistem kalkulasi biaya berdasarkan aktivitas dan produk yang diniai dapat mengukur secara cermat biaya-biaya yang keluar dari setiap aktivitas tersebut. Penelitian ini merupakan penilitian deskriptif yang dilakukan di Rumah Sakit Paru Pamekasan. Data yang digunakan meliputi jenis biaya, laporan besarnya tariff konsumsi makanan, laporan jumlah pasien, laporan lama pasien dan besarnya tenaga listrik (EPS), dan data pendukung lain seperti data luas masing tipe kamar, nama tipe kamar, fasilitas pelayanan dan penunjang layangan di RS Paru Pamekasan.

Hasil penelitian menunjukkan dengan penentuan tarif jasa rawat inap per tipe kamar menggunakan metode Activity Based Costing System (ABCS) memberikan hasil yang lebih tinggi dibandingkan dengan penentuan tarif yang dilakukan oleh RS Paru. Hal ini disebabkan adanya pembebanan biaya overhead pada masing-masing pproduk lebih rinci dengan menggunakan driver. RS Paru Pamekasan diharapkan mengganti sistem penentuan tarif tradisional dengan sistem Activity Based Costing System (ABCS) dalam menentukan tarif rawat inap karena informasi pada sistem ini lebih akurat untuk membantu manajemen dalam proses pengambilan keputusan tarif rawat inap.
\end{abstract}

Kata Kunci :Activity Based Costing System (ABCS)

\section{PENDAHULUAN}

Pelayanan terbaik merupakan salah satu tanggung jawab dari rumah sakit.Rumah sakit dituntut untuk dapat memanfaatkan teknologi dan bidang kesehatan, bidang komunikasi, informasi, dan bidang transportasi yang dapat mendukung jasa pelayanan kesehatan sehingga dapat meningkatkan (Gabriela, 2012).

Menurut Undang-Undang No 44 (2009) Rumah sakit diselenggarakan berasakan pancasila dan didasarkan pada nilai kemanusian, etika dan profesionalitas, manfaat, keadilan, persamaan hak dan anti diskriminasi, pemerataan, perlindungan dan keselamatan pasien serta mempunyai faktor sosial.Bentuk fungsi tugas pelayanan dari rumah sakit adalah penyelenggaraan pelayanan pengobatan dan pemulihan kesehatan sesuai dengan standar pelayanan rumah sakit.Dalam memberikan jasa pelayanan tersebut, rumah sakit menggunakan perolehan pendapatan jasa, salah satunya dari tarif sewa unit rawat inap.

Rumah sakit Paru Pamekasan merupakan salah satu rumah sakit miliki pemerintah yang melayani kesehatan bagi masyarakat sekitar Pamekasan dan luar kota Pamekasan. Ada beberapa unit yang diterapkan oleh rumah sakit ini, diantaranya unit rawat jalan, UGD, unit rawat inap, unit radiologi, unit laboratorium, dan unit farmasi.Dalam perhitungan rawat inap rumah sakit paru Pamekasan masih menggunakan sistem akuntansi biaya tradisional.

Menurut Rudianto (2013) sistem akuntansi tradisional menekankan pada tujuan penentuan harga pokok produk yang dijual.Akibatnya sistem ini hanya menyediakan informasi yang relatif sangat sedikit untuk mencapai keunggulan dalam persaingan global. Akuntansi tradisional juga kurang menekankan pentingnya daur 
hidup, sehingga menyebabkan distorsi harga pokok daur hidup produk.

Penentuan tarif sewa unit kamar inap adalah suatu keputusan yang penting. Hal ini dapat mempengaruhi penentuan biaya yang akurat berkenan dengan biaya pelayanan yang diberikan.Dalam menentukan harga pokok produk, masih ada rumah sakit yang memakai sistem perhitungan akuntansi tradisional.Namun distorsi biaya produk dapat terjadi pada sistem akuntansi biaya tradisional. Distorsi dapat menyebabkan undercost pada hasil produksi. Dalam sistem akuntansi biaya tradisional, distorsi biaya bisa terjadi dikarenakan struktur biaya yang rumit (Carter, 2009).

Metode penghitungan yang dapat digunakan rumah sakit agar tidak mengalami distorsi biaya dalam sistem tradisional adalah dengan menggunakan metode activity based costing system (ABCS). Metode ini menggunakan cost driver yang berdasar pada aktivitas yang menimbulkan biaya, sehingga dianggap mampu mengalokasikan biaya aktivitas di setiap kamar secara tepat berdasarkan konsumsi masing-masing aktivitas. Activity based costing system (ABCS) dapat meningkatkan ketelitian dalam perincian biaya dan ketepatan pembiayaan yang lebih akurat, serta dapat membantu perusahaan jasa dalam mengelola keunggulan kompetitif, kekuatan, kelemahan perusahaan secaraa efisien dengan mengukur aktivitas dan biaya aktivitas di dalam perusahaan jasa rumah sakit (Hidayat, 2012).

Berdasarkan latar belakang diatas, pentingnya perhitungan tarif rumah sakit penulis ingin membuat "Analisis Penentuan Tarif Jasa Rawat Inap dengan Menggunakan Activity Based Costing System (ABCS) di Rumah Sakit Paru Pamekasan".
TINJAUAN PUSTAKA

\section{System}

\section{Activity Based Costing}

Activity based costing system adalah pendekatan penentuan biaya produk yang membebankan biaya ke produk atau jasa berdasarkan konsumsi sumber daya oleh aktivitas. Dasar pemikiran pendekatan penentuan biaya ini adalah bahwa produk atau jasa perusahaan dilakukan oleh aktivitas dan aktivitas yang dibutuhkan tersebut menggunakan sumber daya yang menyebabkan timbulnya biaya (Rudianto, 2013).

Menurut Mulyadi (2003:14) ada empat macam aktivitas, yaitu:

a) Unit-Level Activity, jenis aktivitas yang dikonsumsi oleh produk atau jasa berdasarkan unit yang dihasilkan oleh aktivitas tersebut.

b) Batch - Related Activity, jenis aktivitas yang dikonsumsi oleh produk atau jasa yang dikonsumsi oleh produk yang diproduksi. Batch adalah sekolompok produk atau jasa yang diproduksi dalam satu kali proses.

c) Product - Sustaining Activity, jenis aktivitas yang dikonsumsi oleh produk atau jasa berdasarkan jenis produk yang dihasilkan oleh aktivitas tersebut.

d) Facility - Sustaining Activity, jenis aktivitas yang dikonsumsi oleh produk atau jasa berdasarkan fasilitas yang dinikmati oleh produk yang diproduksi.

Menurut Blocher, et al (2011:212), menjelaskan manfaat dari ABCS adalah:

- $\quad$ ABCS menyajikan biaya produk yang lebih akurat dan informatif, mengaraj pada pengukuran profitabilitas produk dan pelanggan yang lebih akurat serta keputusan strategis yang diinformasikan secara lebih baik mengenai penetapan harga, lini produk dan segmen pasar.

- ABCS menyajikan pengukuran yang lebih akurat mengenai biaya yang dipicu oleh adanya aktivitas. Hal ini dapat membantu manajer untuk membuat keputusan yang lebih baik 
mengenai desain produk serta nilai produk.

- ABCS menyediakan informasi untuk mengidentifikasi bidang-bidang dimana perbaikan proses dibutuhkan.

- ABCS meningkatkan biaya produk yang mengarah pada estimasi biaya pesanan yang lebih baik untuk keputusan penetapan harga, penganggaran dan perencanaan.

- ABCS menyediakan informasi yang lebih baik untuk mengidentifikasi biaya dari kapasitas yang tidak digunakan dan mempertahankan akuntansi secara terpisah untuk biaya tersebut.

\section{Tahap- Tahap Penerapan Activity Based Costing System (ABCS)}

Menurut Blocher, Stout dan Cokins (2011:207) ada beberapa tahap dalam perhitungan ABCS diantaranya:

1. Mengidentifikasi sumber daya dan aktivitas

2. Membebankan biaya sumber daya ke aktivitas

3. Membebankan biaya aktivitas ke objek biaya

Hal-hal yang perlu diperhatikan dalam penerapan ABCS pada perusahaan jasa adalah:

1. Identifying and costing activities

Mengidentifikasi dan menghargai aktivitas dapat membuka beberapa kesempatan untuk pengoperasian yang efisien

2. Special Challenger

Perbedaan antara perusahaan jasa dan perusahaan manufaktur akan memiliki permasalahan-permasalahan yang serupa. Permasalahan itu seperti sulitnya mengalokasikan biaya ke aktivitas.Selain itu jasa tidak dapat menjadi suatu persediaan, karena kapasitas yang ada namun tidak dapat digunakan menimbulkan biaya yang tidak dapat dihindari.

\section{Output diversity}

Perusahaan jasa juga memiliki kesulitan-kesulitan dalam melakukan identifikasi output yang ada. Pada perusahaan jasa, diversity yang menggambarkan aktivitas-aktivitas pendukung pada hal-hal yang berbeda mungkin sulit untuk dijelaskan atau ditentukan dengan rumus:

Tarif per kamar = Cost sewa + laba yang diharapkan

\section{Syarat Penerapan Sistem ABCS}

Penentuan harga pokok

dengan menggunakan sistem ABCS

mensyaratkan 3 hal:

1. Perusahaan mempunyai tingkat diversitas yang tinggi

$$
\text { Artinya perusahaan }
$$

memproduksi beberapa macam produk atau lini produk yang diproses dengan menggunakan fasilitas yang sama. Contohnya pada rumah sakit dengan produk yang bervariasi "perawatan dan penginapan". Selama menginap seorang pasien akan mendapatkan berbagai jasa misalnya perawatan harian yang terdiri dari 3 kegiatan: penginapan, pemberi makan, dan perawatan. Kondisi semacam ini akan menimbulkan masalah dalam membebankan biaya ke masingmasing produk.

2. Tingkat persaingan industri yang tinggi Ada beberapa perusahaan yang menghasilkan produk yang sama atau sejenis. Dalam persaingan antar perusahaan yang sejenis tersebut maka perusahaan akan semakin meningkatkan persaingan untuk memperbesar pasarnya. Semakin besar tingkat persaingan maka semakin penting peran informasi tentang harga pokok dalam mendukung pengambilan keputusan manajemen.

3. Biaya pengukuran yang rendah

Biaya yang digunakan sistem ABCS untuk menghasilkan informasi biaya yang akurat harus lebih rendah dibandingkan dengan manfaat yang diperoleh.

\section{Pemicu Biaya (Cost Driver)}

Cost driver atau activity driver merupakan suatu yang menjadi penyebab timbulnya konsumsi aktivitas oleh produk atau jasa dan menjadi basis yang digunakan untuk membebankan biaya 
aktivitas ke produk atau jasa yang memanfaatkan aktivitas tersebut.

Menurut Gabriela (2012), cost driver adalah kejadian atau aktivitas yang menyebabkan atau berakibat keluarnya biaya. Ada tiga faktor dalam memilih cost driver sebagai berikut:

a) Degree of correlation (tingkat korelasi). Konsep dasar ABCS adalah membebankan biaya-biaya dari setiap aktivitas ke lini produk, berdasarkan pada bagaimana setiap lini produk mengkonsumsi cost driver. Oleh karena itu, keakuratan pengalokasian setiap biaya tergantung pada tingkat korelasi antara konsumsi aktivitas dan konsumsi cost driver.

b) Cost measurement. Perancangan sistem informasi memerlukan cost benefit trade offs. Jumlah activity cost pool yang terdapat dalam sistem ABCS yang lebih banyak memerlukan cost driver, menyebabkan biaya implementasi menjadi lebih besar. Namun demikian, korelasi yang tinggi antara cost driver dan konsumsi sesungguhnya dari setiap aktivitas menyebabkan perhitungan harga pokok semakin akurat.

c) Behavioural effect. Sistem informasi berpotensi tidak hanya untuk memfasilitasi keputusan, tetapi juga mempengaruhi perilaku pengambil keputusan. Dalam mengidentifikasi cost driver, analisis ABCS perlu mempertimbangkan kemungkinan konsekuensi keperilakuan.

Rayburn (1999:142) dan Blocher et al (2002:581) menyatakan ada 2 jenis cost driver yaitu:

1. Cost driver berdasarkan unit/volume Cost driver berdasarkan

unit membebankan atau mengalokasikan biaya overhead pada produk melalui penggunaan tarif overhead tunggal oleh seluruh departemen.

2. Cost driver berdasarkan non unit Merupakan faktor penyebab selalin unit yang menjelaskan konsumsi overhead. Contoh cost driver berdasarkan unit pada perusahaan jasa adalah luas lantai, jumlah pasien, dan jumlah kamar yang tersedia.

\section{Perbedaan antara ABC System dengan Akuntansi Biaya Tradisional}

Menurut Carter

(2009:532)

menjelaskan perbandingan antara metode Activity Based Costing dengan metode Tradisional Costing diantaranya sebagai berikut:

1) Sistem ABCS mengharuskan penggunaan tempat penampungan overhead lebih dari satu, tetapi tidak setiap sistem dengan tempat penampungan biaya dari satu adalah sistem ABCS.

2) Jumlah tempat penampungan biaya overhead dan dasar alokasi cenderung lebih banyak sistem tradisional menggunakan satu tempat penampungan biaya atau satu dasar alokasi untuk semua tempat penampungan biaya.

3) Perbedaan umum antara sistem $A B C$ dan sistem tradisional adalah homogenitas dari biaya dalam satu dasar alokasi untuk semua tempat penampungan biaya.

4) Perbedaaan lain antara sistem ABCS dan sistem tradisional adalah semua sistem ABCS merupakan sistem perhitungan biaya dua tahap, sementara sistem tradisional bisa merupakan sistem perhitungan satu atau dua tahap.

\section{METODOLOGI PENELITIAN}

Penelitian ini dilakukan di Rumah Sakit Paru Pamekasan.Jenis penelitian ini adalah penelitian deskriptif. Data yang digunakan meliputi jenis biaya, laporan besarnya tariff konsumsi makanan, laporan jumlah pasien, laporan lama pasien dan besarnya tenaga listrik (EPS), dan data pendukung lain seperti data luas masing tipe kamar, nama tipe kamar, fasilitas pelayanan dan penunjang layangan di RS Paru Pamekasan periode 2014. 
Teknik Analisis Data

Langkahh-langkah yang digunakan dalam penelitian ini dengan menggunakanActivity Based Costing System menurut Hansen dan Mowen (1999: 322 - 324) sebagai berikut:

- Mengidentifikasi aktivitas

- Mengklasifikasi biaya berdasar aktivitas ke dalam berbagai aktivitas

- Mengidentifikasi cost driver

- Menentukan tarif per unit cost

Tarif per unit cost driver $=$

\section{Jumlah aktivitas / Cost}

\section{driver}

- Membebankan biaya ke produk dengan menggunakan tarif cost driver dan ukuran aktivitas

1. Pembebanan biaya overhead dari aktivitas ke setiap kamar

$$
\text { BOP }
$$

yang

dibebankan =

Tarif per unit cost driver $\mathrm{x}$ cost driver

2. Kemudian perhitungan tarif masingmasing tipe kamar dengan metode activity based costing system dapat dihitung dengan rumus:

\section{Tarif per kamar =}

Cost sewa + laba yang diharapkan

\section{ANALISIS DAN PEMBAHASAN}

Ada 4 kategori kelas yang

diterapkan di RS Paru Pamekasan diantaranya dapat dilihat di tabel berikut ini:
Tabel 1

Tabel Tarif dan Fasilitas Kamar Perawatan

\begin{tabular}{|c|c|c|c|}
\hline Kelas & Tarif & i/pasien) & Fasilitas \\
\hline \multirow{6}{*}{ VIP } & \multirow{6}{*}{$\mathrm{Rp}$} & \multirow{6}{*}{590,000} & a. 1 Tempat tidur pasien \\
\hline & & & b. 1 Tempat tidur tunggu \\
\hline & & & c. Kamar mandi dalam \\
\hline & & & d. Meja Obat \\
\hline & & & e. Lemari Pasien \\
\hline & & & f. TV, AC, Lemari Es \\
\hline \multirow{6}{*}{ I } & \multirow{6}{*}{$\operatorname{Rp}$} & \multirow{6}{*}{445,000} & a. 1 Tempat Tidur Pasien \\
\hline & & & b. 1 Sofa tunggu \\
\hline & & & c. Kamar mandi dalam \\
\hline & & & d. Meja Obat \\
\hline & & & e. Lemari pasien \\
\hline & & & f. TV, AC, Lemari Es \\
\hline \multirow{5}{*}{$\|$} & \multirow{5}{*}{$\operatorname{Rp}$} & \multirow{5}{*}{335,000} & a. 2 Tempat tidur pasien \\
\hline & & & b. Kamar mandi dalam \\
\hline & & & c. Meja Obat \\
\hline & & & d. Lemari Pasien \\
\hline & & & e. 1 Kipas angin \\
\hline \multirow{5}{*}{ III } & \multirow{5}{*}{$\mathrm{Rp}$} & \multirow{5}{*}{215,000} & a. 5 Tempat tidur pasien \\
\hline & & & b. Kamar mandi dalam \\
\hline & & & c. Meja Obat \\
\hline & & & d. Lemari Pasien \\
\hline & & & e. 1 Kipas angin \\
\hline
\end{tabular}

Sakit Paru Pamekasan

Dalam menetapkan harga pokok rawat inap, rumah sakit mengkategorikan biaya-biaya yang ada menjadi dua macam, yaitu:

1. Biaya Tetap, biaya depresiasi yaitu biaya atas investasi. Biaya tersebut meliputi biaya depreasi gedung dan depresiasi fasilitas.

2. Biaya Variabel, biaya operasional unit jasa rawat inap. Biaya yang diperlukan pada saat kegiatan produksi yang bersifat habis pakai atau relatif singkat. Biaya-biaya tersebut adalah biaya perawat, biaya bahan habis pakai, biaya konsumsi, biaya listrik dan air, serta biaya administrasi.

Berdasarkan hasil perolehan data dari bagian administrasi, diketahui terdapat biaya yang disebabkan oleh unit rawat inap tetapi aktivitas-aktivitas biaya tersebut belum dibebankan sebagai biaya.Diantaranya adalah biaya laundry, 
biaya kebersihan dan biaya pemeliharaan alat dokter.

Tabel 2

Data Pendukung Luas

Kamar Rawat Inap dan Jumlah Kamar

Tabel 3

Rumah Sakit Paru Pamekasan

\begin{tabular}{|c|c|c|c|c|}
\hline TIPE KAMAR & LUAS KAMAR & JUMLAH KAMAR & \multicolumn{2}{|c|}{ Paru Pamekasan } \\
\hline VIP & $460 \mathrm{~m}^{2}$ & 5 Kamar & & \\
\hline Kelas I & $370 \mathrm{~m}^{2}$ & 6 Kamar & TIPE KAMAR & Tarif Konsumsi/Har \\
\hline Kelas II & $450 \mathrm{~m}^{2}$ & 7 Kamar & VIP & 45,000 \\
\hline Kelas III & $420 \mathrm{~m}^{2}$ & T Namial & Kelas I & 30,000 \\
\hline & & & \multirow[t]{2}{*}{ Kelas II } & $\mathrm{Rp}$ \\
\hline TOTAL & $1700 \mathrm{~m}^{2}$ & 25 Kamar & & $\mathrm{Rn}$ \\
\hline
\end{tabular}

Adapun data pendukung tarif konsumsi yang diberikan oleh rumah sakit paru pamekasan pada tiap-tiap kelas terdapat perbedaan sesuai dengan tiap kelas rawat inap.Konsumsi diberikan 3 kali sehari yaitu pada pagi, siang, dan sore hari
Sumber : Rumah Sakit Paru Pamekasan

Rincian macam-macam biaya rawat inap yang akan dibebankan membutuhkan driver jumlah pasien yang menjalani rawat inap pada masing-masing tipe kamar dan driver lama hari pasien rawat inap dalam satu tahun seperti biaya administrasi dan sebagainya.

Tabel 5

Data Macam-Macam Biaya Rawat Inap Rumah Sakit Paru Pamekasan

\begin{tabular}{|c|l|rr|}
\hline No & \multicolumn{1}{|c|}{ Elemen Biaya } & \multicolumn{2}{|c|}{ Jumlah } \\
\hline 1 & Biaya Laundry & $\mathrm{Rp}$ & $52,780,450$ \\
\hline 2 & Biaya Kebersihan & $\mathrm{Rp}$ & $130,850,000$ \\
\hline 3 & Biaya Konsumsi & $\mathrm{Rp}$ & $284,000,000$ \\
\hline 4 & Biaya Listrik dan Air & $\mathrm{Rp}$ & $725,000,000$ \\
\hline 5 & Biaya Gaji Tenaga Medis & $\mathrm{Rp}$ & $890,300,000$ \\
\hline 6 & Biaya Penyusutan Gedung & $\mathrm{Rp}$ & $398,700,160$ \\
\hline 7 & Biaya Penyusutan Fasilitas & $\mathrm{Rp}$ & $65,370,309$ \\
\hline 8 & Biaya Administrasi & $\mathrm{Rp}$ & $575,000,000$ \\
\hline 9 & Biaya Pemeliharaan Alat Dokter & $\mathrm{Rp}$ & $68,500,300$ \\
\hline 10 & Biaya Bahan Habis Pakai & $\mathrm{Rp}$ & $535,230,000$ \\
\hline
\end{tabular}

Sumber : Rumah Sakit Paru Pamekasan 
ISSN 1412-2936

Tabel 6

Data Pendukung Lama Hari Pasien Rawat Inap Rumah Sakit Paru Pamekasan

\begin{tabular}{|l|c|c|c|c|}
\hline \multicolumn{1}{|c|}{ BULAN } & VIP & KELAS I & KELAS II & KELAS III \\
\hline Januari & 120 & 150 & 284 & 350 \\
\hline Februari & 115 & 129 & 242 & 410 \\
\hline Maret & 110 & 130 & 286 & 250 \\
\hline April & 130 & 150 & 276 & 304 \\
\hline Mei & 125 & 140 & 291 & 325 \\
\hline Juni & 90 & 100 & 306 & 298 \\
\hline Juli & 180 & 196 & 265 & 225 \\
\hline Agustus & 143 & 152 & 369 & 320 \\
\hline September & 132 & 200 & 383 & 231 \\
\hline Oktober & 165 & 175 & 276 & 210 \\
\hline November & 76 & 100 & 244 & 242 \\
\hline Desember & 152 & 165 & 235 & 292 \\
\hline Jumlah & 1538 & 1787 & 3457 & 3457 \\
\hline TOTAL & \multicolumn{5}{|c|}{10239} \\
\hline
\end{tabular}

Sumber : Rumah Sakit Paru Pamekasan

Tabel 7

Penggunaan Tenaga Listrik Rumah Sakit Paru Pamekasan

\begin{tabular}{|l|c|}
\hline \multicolumn{1}{|c|}{ Tipe Kamar } & KWH \\
\hline VIP & 20250 \\
\hline Kelas I & 12700 \\
\hline Kelas II & 12050 \\
\hline Kelas III & 10000 \\
\hline Jumlah & 55000 \\
\hline
\end{tabular}

Klasifikasi biaya ke dalam berbagai aktivitas dapat dikelompokkan pada tabel berikut ini.

Tabel 8

Klasifikasi Biaya Ke Dalam Berbagai Aktivitas

\begin{tabular}{|l|ll|}
\hline \multicolumn{3}{|c|}{ Unit Level Activity Cost } \\
\hline Biaya Gaji Tenaga Medis & $\mathrm{Rp}$ & $890,300,000$ \\
\hline Biaya Listrik dan Air & $\mathrm{Rp}$ & $725,000,000$ \\
\hline Biaya Konsumsi & $\mathrm{Rp}$ & $284,000,000$ \\
\hline \multicolumn{3}{|c|}{ Batch Related Activity Cost } \\
\hline Biaya Kebersihan & $\mathrm{Rp}$ & $130,850,000$ \\
\hline Biaya Administrasi & $\mathrm{Rp}$ & $575,000,000$ \\
\hline Biaya Bahan Habis Pakai & $\mathrm{Rp}$ & $535,230,000$ \\
\hline
\end{tabular}

Facility Sustaining Activity Cost

\begin{tabular}{|c|c|c|}
\hline Biaya Penyusutan Laundry & $\mathrm{Rp}$ & $52,780,450$ \\
\hline Biaya Penyusutan Gedung & $\mathrm{Rp}$ & $398,700,160$ \\
\hline Biaya Penyusutan Fasilitas & $R p$ & $65,370,309$ \\
\hline Biaya Pemeliharaan Alat Dokter & $\overline{R p}$ & $68,500,300$ \\
\hline IUIAL & Rp & $, / 25, / 31,219$ \\
\hline
\end{tabular}

Makro, Jurnal Manajemen \& Kewirausahaan, Volume 1 No.01| Mei 2016 
Menentukan Tarif per Unit Pemicu Biaya (Cost Driver)

Menurut Hansen dan Mowen (1999:134) tarif per unit cost driver dapat dihitung dengan rumus sebagai berikut:

Tarif per Unit Cost Driver $=\frac{\text { Jumlah aktivitas }}{\text { Cost Driver }}$

Dalam penentuan tarif per unit cost driver kamar rawat inap dengan metode Activity Based Costing System yaitu membebankan atau membagi jumlah aktivitas dari jenis-jenis biaya yang sudah ditentukan kepada cost driverdari masingmasing tipe kamar.

\section{Biaya Gaji Tenaga Medis}

Tarif per Unit Cost Driver $=\frac{\text { Bi. Gaji Ten. Medis }}{\text { Tot. hari rawatinap }}$

$$
=\frac{\mathrm{Rp} \cdot 890.300 .000}{10.039 \text { Hari }}
$$

$$
=\text { Rp. } 88.684,13
$$

\section{Biaya Listrik dan Air}

Tarif per Unit Cost Driver $=\frac{\text { Bi. Listrik dan Air }}{\text { Jumlah }}$

$$
=\frac{\mathrm{Rp} .725 .000 .000}{55.000 \mathrm{KWH}}
$$$$
=\operatorname{Rp} \cdot 13 \cdot 181,81
$$

\section{Biaya Konsumsi}

Tarif per Unit Cost Driver $=\frac{\text { Bi. Konsumsi }}{\text { Tot. hari rawat inap }}$

$$
=\frac{\mathrm{Rp} \cdot 284.000 .000}{10.039}
$$

$=$ Rp. $28.289,67$

\section{Biaya Kebersihan}

$$
\begin{aligned}
\text { Tarif per Unit Cost Driver } & =\frac{\text { Bi. Kebersihan }}{\begin{array}{l}
\text { Jumlah seluruh } \\
\text { luas tipe kamar }
\end{array}} \\
& =\frac{\text { Rp. } 130.850 .000}{1.700} \\
& =\text { Rp. } 76.970,58
\end{aligned}
$$

\section{Biaya Bahan Habis Pakai}

Tarif per Unit Cost Driver

$$
\begin{gathered}
=\frac{\text { Bi. Bahan Habis Pakai }}{\text { Tot. hari rawat inap }} \\
=\frac{\text { Rp.535.230.000 }}{10.039 \text { hari }}
\end{gathered}
$$

$$
=\text { Rp. } 53.513,07
$$

\section{Biaya Administrasi}

$$
\begin{aligned}
& \text { Tarif per Unit Cost Driver }=\frac{\text { Bi. Administrasi }}{\text { Juml pasien }} \\
& \text { seluruh tipe kamar } \\
&=\frac{\text { Rp. } 575.000 .000}{3.039 \text { hari }} \\
&=\text { Rp. } 189.206,97
\end{aligned}
$$

\section{Biaya Laundry}

Tarif per Unit Cost Driver $=\frac{\text { Bi. Laundry }}{\text { Tot hari rawat inap }}$

$$
=\frac{\text { Rp.52.780.450 }}{10.039 \text { hari }}
$$


$=$ Rp. $5 \cdot 257,24$

\section{Biaya Pemeliharaan Alat Dokter}

$$
\begin{aligned}
\text { Tarif per Unit Cost Driver } & =\frac{\begin{array}{c}
\text { Bi. Pemeliharaan } \\
\text { alat dokter }
\end{array}}{\text { Tot. hari rawat inap }} \\
& =\frac{\text { Rp. } 68.500 .300}{10.039 \text { hari }} \\
& =\text { Rp. } 6.823,41
\end{aligned}
$$

\section{Biaya Penyusutan Gedung}

$$
\begin{aligned}
\text { Tarif per Unit Cost Driver } & =\frac{\begin{array}{c}
\text { Bi. Penyusutan } \\
\text { gedung }
\end{array}}{\begin{array}{c}
\text { Jumlah seluruh luas } \\
\text { tipe kamar }
\end{array}} \\
& =\frac{\text { Rp.398.700.160 }}{1700} \\
& =\text { Rp. } 234.529,50
\end{aligned}
$$

\section{Biaya Penyusutan Fasilitas}

Tarif per Unit Cost Driver $=\frac{\text { Bi. penyusutan AC }}{\text { Juml. hari rawat inap }}$ VIP dan Kelas I

$$
\begin{aligned}
& =\frac{\text { Rp.10.392.000 }}{3325 \text { hari }} \\
& =\text { Rp. 3.125,41 }
\end{aligned}
$$

Tarif per Unit Cost Driver $=$

$$
\text { Bi. penyusutan }
$$

Juml. hari rawatinap VIP

$$
=\frac{\text { Rp. } 4.400 .665}{1.538 \text { hari }}
$$

$=$ Rp. $2 \cdot 861,29$

Bi. penyusutan

Tarif per Unit Cost Driver $=\frac{\text { kipas angin }}{\text { Juml. hari rawat inap }}$ kelas I dan II

$$
\begin{gathered}
=\frac{\text { Rp.4.250.000 }}{6 \cdot 714 \text { hari }} \\
=\text { Rp. } 633,01
\end{gathered}
$$

$$
\begin{aligned}
& \text { Tarif per Unit Cost Driver }= \frac{\text { Bi. penyusutan }}{\text { TV }} \\
& \begin{array}{c}
\text { Juml. hari rawat inap } \\
\text { VIP dan Kelas I }
\end{array} \\
&=\frac{\text { Rp.3.950.000 }}{3.325 \text { hari }}
\end{aligned}
$$

$$
=\operatorname{Rp} \cdot 1 \cdot 187,96
$$

Menurut Hansen dan Mowen (1999:138), biaya aktivitas dibebankan ke produk berdasarkan konsumsi masingmasing aktivitas produk.Artinya yang dapat menimbulkan biaya ditelusuri ke produk yang disesuaikan dengan berapa banyak kegiatan produk yang digunakan.

Pembebanan biaya overhead dari tiap aktivitas setiap kamar dihitung dengan rumus sebagai berikut:

\section{BOP yang dibebankan = Tarif per unit cost driver $x$ cost driver yang dipilih}

Mulyadi (1999:98) menyatakan tarif masing-masing tipe kamar dengan metode $A B C$ dapat dihitung dengan rumus sebagai berikut:

\section{Tarif per kamar = Cost rawat inap + laba yang diharapkan}

Dari tipe per kamar yang ada di rumah sakit mengharapkan laba dari tarif jasa rawat inap, sedangkan laba yang diharapkan ditetapkan oleh pihak manajemen rumah sakit, yaitu : VIP 25\%, kelas I 24\%, kelas II 23\%, dan kelas III $15 \%$. 
Tabel 9

Tarif Jasa Rawat Inap Kelas VIP

\begin{tabular}{|c|c|c|c|c|c|}
\hline No & Aktivitas & $\begin{array}{l}\text { Tarif Per Cost } \\
\text { Driver }\end{array}$ & Driver & & Jumlah \\
\hline 1 & Biaya Laundry & Rp $\quad 5,257.54$ & 1538 hari & Rp & $8,086,096.52$ \\
\hline 2 & Biaya Kebersihan & Rp $76,970.58$ & $460 \mathrm{~m}^{2}$ & $\mathrm{Rp}$ & $35,406,467$ \\
\hline 3 & Biaya Konsumsi & Rp $28,289.67$ & 1538 hari & $\mathrm{Rp}$ & $43,509,512$ \\
\hline 4 & Biaya Listrik dan Air & $\operatorname{Rp} 13,181.81$ & $20250 \mathrm{KWH}$ & $\mathrm{Rp}$ & $266,931,653$ \\
\hline 5 & Biaya Gaji Tenaga Medis & $\mathrm{Rp} \quad 88,684.13$ & 1538 hari & $\mathrm{Rp}$ & $136,396,192$ \\
\hline 6 & Biaya Administrasi & Rp 189,206.97 & 221 pasien & $\mathrm{Rp}$ & $41,814,740.37$ \\
\hline 7 & Biaya Bahan Habis Pakai & Rp $53,315.07$ & 1538 hari & $\mathrm{Rp}$ & $81,998,577.66$ \\
\hline 8 & $\begin{array}{l}\text { Biaya Pemeliharaan Alat } \\
\text { Dokter }\end{array}$ & $\mathrm{Rp} \quad 6,823.41$ & 1538 hari & $\mathrm{Rp}$ & $10,494,404.58$ \\
\hline 9 & Biaya Penyusutan Gedung & Rp 234,529.50 & $460 \mathrm{~m}^{2}$ & $\mathrm{Rp}$ & $107,883,570$ \\
\hline \multirow[t]{4}{*}{10} & \multicolumn{2}{|l|}{ Biaya Penyusutan Fasilitas: } & & & \\
\hline & Kulkas & Rp $\quad 2,861.29$ & 1538 hari & Rp & $4,400,664.02$ \\
\hline & Televisi & $\begin{array}{ll}\mathrm{Rp} & 1,187.96\end{array}$ & 1538 hari & $\mathrm{Rp}$ & $1,827,082.48$ \\
\hline & $A C$ & $\mathrm{Rp} \quad 3,125.41$ & 1538 hari & $\mathrm{Rp}$ & $4,806,880.58$ \\
\hline \multicolumn{4}{|c|}{ TOTAL BIAYA VIP } & \multicolumn{2}{|c|}{ Rp $743,555,839.91$} \\
\hline \multicolumn{4}{|c|}{ JUMLAH HARI PAKAI } & \multicolumn{2}{|r|}{1538 Hari } \\
\hline \multicolumn{4}{|c|}{ B IAYA RAWAT INAP PER KAMAR } & $\mathrm{Rp}$ & $483,456.33$ \\
\hline \multicolumn{4}{|c|}{ PROSENTASE LABA 25\% } & $\mathrm{Rp}$ & $120,864.08$ \\
\hline \multicolumn{4}{|c|}{ TARIF JASA RAWAT INAP VIP } & Rp & $604,320.42$ \\
\hline
\end{tabular}

Berdasarkan perhitungan tarif jasa rawat inap pada kelas VIP dengan menggunakan $A B C S$ di rumah sakit paruparu pamekasan dihasilkan tarif sebesar Rp.604.320,42 dengan tingkat keuntungan yang diharapkan $25 \%$. Hal ini lebih besar dibandingkan dengan tarif yang selama ini diterapkan oleh RS Paru Pamekasan sebesar Rp.590.000. Ada selisih
Rp.14.320,55. Hal ini disebabkan biaya yang diberlakukan oleh RS Paru Pamekasan masih menggunakan tarif dasar yang ada di pasaran dan perkiraan pembebanan biaya yang dikeluarkan pasien, sehingga terjadi penetapan tarif jasa rawat inap yang rendah dibandingkan dengan menggunakan ABCS. 
Sedangkan untuk perhitungan penentuan tarif jasa rawat inap kelas I menggunakan metode activity based costing system diperoleh tarif jasa sebesar Rp.485.909,18 dengan tingkat keuntungan yang diharapkan $24 \%$. Ada selisih sebesar Rp.40.909,18 dari tarif yang diterapkan RS Paru Pamekasan sebesar Rp.445.000.

Hasil perhitungan tarif jasa rawat inap kelas II juga tidak jauh berbeda. Tarif yang dihasilkan dengan ABCS sebesar

Rp.360.095,44 dengan tingkat keuntungan $23 \%$. Terdapat selisih tarif jasa rawat inap sebesar Rp25.095,44 dari tarif yang diberlakukan RS Paru Pamekasan sebesar Rp.335.000.

Untuk hasil penghitungan dapat dilihat pada tabel dibawah ini:

Tabel 10

Tarif Jasa Rawat Inap Kelas I

\begin{tabular}{|c|c|c|c|c|c|c|}
\hline No & Aktivitas & \multicolumn{2}{|c|}{$\begin{array}{c}\text { Tarif Per Cost } \\
\text { Driver }\end{array}$} & Driver & \multicolumn{2}{|r|}{ Jumlah } \\
\hline 1 & Biaya Laundry & $\mathrm{Rp}$ & $5,257.54$ & 1787 hari & $\mathrm{Rp}$ & $9,395,223.98$ \\
\hline 2 & Biaya Kebersihan & $\mathrm{Rp}$ & $76,970.58$ & $370 \mathrm{~m}^{2}$ & $\mathrm{Rp}$ & $28,479,115$ \\
\hline 3 & Biaya Konsumsi & $\mathrm{Rp}$ & $28,289.67$ & 1787 hari & $\mathrm{Rp}$ & $50,553,640.29$ \\
\hline 4 & Biaya Listrik dan Air & $\mathrm{Rp}$ & $13,181.81$ & $12700 \mathrm{KWH}$ & $\mathrm{Rp}$ & $167,408,987$ \\
\hline 5 & Biaya Gaji Tenaga Medis & $R p$ & $88,684.13$ & 1787 hari & $\mathrm{Rp}$ & $158,478,540.31$ \\
\hline 6 & Biaya Administrasi & $\mathrm{Rp}$ & $189,206.97$ & 474 pasien & $\mathrm{Rp}$ & $89,684,103.78$ \\
\hline 7 & Biaya Bahan Habis Pakai & $\mathrm{Rp}$ & $53,315.07$ & 1787 hari & $\mathrm{Rp}$ & $95,274,030.09$ \\
\hline 8 & Biaya Pemeliharaan Alat Dokter & $\mathrm{Rp}$ & $6,823.41$ & 1787 hari & $\mathrm{Rp}$ & $12,193,433.67$ \\
\hline 9 & Biaya Penyusutan Gedung & $\mathrm{Rp}$ & $234,529.50$ & $370 m^{2}$ & $\mathrm{Rp}$ & $86,775,915$ \\
\hline$\overline{10}$ & Biaya Penyusutan Fasilitas & & & & & \\
\hline & Televisi & $\mathrm{Rp}$ & $1,187.96$ & 1787 hari & $\mathrm{Rp}$ & $2,122,884.52$ \\
\hline & $A C$ & $\mathrm{Rp}$ & $3,125.41$ & 1787 hari & $\mathrm{Rp}$ & $5,585,107.67$ \\
\hline \multicolumn{5}{|c|}{ TOTAL BIAYA VIP } & $\mathrm{Rp}$ & $705,950,980.91$ \\
\hline \multicolumn{5}{|c|}{ JUMLAH HARI PAKAI } & & $1787 \mathrm{har}$ \\
\hline \multicolumn{5}{|c|}{ B IAYA RAWAT INAP PER KAMAR } & $\mathrm{Rp}$ & $395,048.11$ \\
\hline \multicolumn{5}{|c|}{ PROSENTASE LABA 24\% } & $\mathrm{Rp}$ & $90,861.07$ \\
\hline \multicolumn{5}{|c|}{ TARIF JASA RAWAT INAP KELAS I } & $\mathrm{Rp}$ & $485,909.18$ \\
\hline
\end{tabular}


Tabel 11

Tarif Jasa Rawat Inap Kelas II

\begin{tabular}{|c|c|c|c|c|c|c|}
\hline No & Aktivitas & \multicolumn{2}{|c|}{$\begin{array}{c}\text { Tarif Per Cost } \\
\text { Driver }\end{array}$} & Driver & \multicolumn{2}{|r|}{ Jumlah } \\
\hline 1 & Biaya Laundry & $\mathrm{Rp}$ & $5,257.54$ & 3257 hari & $\overline{\mathrm{Rp}}$ & $17,123,807.78$ \\
\hline 2 & Biaya Kebersihan & $\mathrm{Rp}$ & $76,970.58$ & $450 \mathrm{~m}^{2}$ & $\mathrm{Rp}$ & $34,636,761$ \\
\hline 3 & Biaya Konsumsi & $\mathrm{Rp}$ & $28,289.67$ & 3257 hari & $\overline{R p}$ & $92,139,455.19$ \\
\hline 4 & Biaya Listrik dan Air & $\mathrm{Rp}$ & $13,181.81$ & $12050 \mathrm{KWH}$ & $\mathrm{Rp}$ & $158,840,810.5$ \\
\hline 5 & Biaya Gaji Tenaga Medis & $\mathrm{Rp}$ & $88,684.13$ & 3257 hari & $R p$ & $288,844,211.41$ \\
\hline 6 & Biaya Administrasi & $\mathrm{Rp}$ & $189,206.97$ & 309 pasien & $\mathrm{Rp}$ & $58,464,953.73$ \\
\hline 7 & Biaya Bahan Habis Pakai & $\mathrm{Rp}$ & $53,315.07$ & 3257 hari & $R p$ & $173,647,182.99$ \\
\hline 8 & Biaya Pemeliharaan Alat Dokter & $\mathrm{Rp}$ & $6,823.41$ & 3257 hari & $\mathrm{Rp}$ & $22,223,846.37$ \\
\hline 9 & Biaya Penyusutan Gedung & $\mathrm{Rp}$ & $234,529.50$ & $450 \mathrm{~m}^{2}$ & $\mathrm{Rp}$ & $105,538,275$ \\
\hline \multirow[t]{2}{*}{10} & Biaya Penyusutan Fasilitas : & & & & & \\
\hline & Kipas Angin & $\mathrm{Rp}$ & 633.01 & 3257 hari & $\mathrm{Rp}$ & $2,061,713.57$ \\
\hline \multicolumn{5}{|c|}{ TOTAL BIAYA VIP } & $\mathrm{Rp}$ & $953,521,017.54$ \\
\hline \multicolumn{5}{|c|}{ JUMLAH HARI PAKAI } & & 3257 hari \\
\hline \multicolumn{5}{|c|}{ B IAYA RAWAT INAP PER KAMAR } & $\mathrm{Rp}$ & $292,760.52$ \\
\hline \multicolumn{5}{|c|}{ PROSENTASE LABA 23\% } & $\mathrm{Rp}$ & $67,334.92$ \\
\hline \multicolumn{5}{|c|}{ TARIF JASA RAWAT INAP KELAS II } & $\mathbf{R p}$ & $360,095.44$ \\
\hline
\end{tabular}

Tabel 12

Tarif Jasa Rawat Inap Kelas III

\begin{tabular}{|c|c|c|c|c|c|c|}
\hline No & Aktivitas & \multicolumn{2}{|c|}{$\begin{array}{c}\text { Tarif Per Cost } \\
\text { Driver }\end{array}$} & Driver & \multicolumn{2}{|r|}{ Jumlah } \\
\hline 1 & Biaya Laundry & $\mathrm{Rp}$ & $5,257.54$ & 3457 hari & $\mathrm{Rp}$ & $18,175,315.78$ \\
\hline 2 & Biaya Kebersihan & $\mathrm{Rp}$ & $76,970.58$ & $420 \mathrm{~m}^{2}$ & $\mathrm{Rp}$ & $32,327,644$ \\
\hline 3 & Biaya Konsumsi & $\overline{R p}$ & $28,289.67$ & 3457 hari & $\mathrm{Rp}$ & $97,797,389.19$ \\
\hline 4 & Biaya Listrik dan Air & $\mathrm{Rp}$ & $13,181.81$ & $10000 \mathrm{KWH}$ & $\mathrm{Rp}$ & $131,818,100.0$ \\
\hline 5 & Biaya Gaji Tenaga Medis & $\mathrm{Rp}$ & $88,684.13$ & 3457 hari & $\mathrm{Rp}$ & $306,581,037.41$ \\
\hline 6 & Biaya Administrasi & $\mathrm{Rp}$ & $189,206.97$ & 2035 pasien & $\mathrm{Rp}$ & $385,036,183.95$ \\
\hline 7 & Biaya Bahan Habis Pakai & $\mathrm{Rp}$ & $53,315.07$ & 3457 hari & $\mathrm{Rp}$ & $184,310,196.99$ \\
\hline 8 & Biaya PemeliharaanAlat Dokter & $\mathrm{Rp}$ & $6,823.41$ & 3457 hari & $\mathrm{Rp}$ & $23,588,528.37$ \\
\hline 9 & Biaya Penyusutan Gedung & $\mathrm{Rp}$ & $234,529.50$ & $420 \mathrm{~m}^{2}$ & $\mathrm{Rp}$ & $98,502,390$ \\
\hline \multirow[t]{2}{*}{10} & Biaya Penyusutan Fasilitas: & & & & & \\
\hline & Kipas Angin & $\mathrm{Rp}$ & 633.01 & 3457 hari & $\mathrm{Rp}$ & $2,188,315.57$ \\
\hline \multicolumn{5}{|c|}{ TOTAL BIAYA VIP } & $\mathrm{Rp}$ & $1,280,325,100.86$ \\
\hline \multicolumn{5}{|c|}{ JUMLAH HARI PAKAI } & & 3457 hari \\
\hline \multicolumn{5}{|c|}{ B IAYA RAWAT INAP PER KAMAR } & $\mathrm{Rp}$ & $370,357.28$ \\
\hline \multicolumn{5}{|c|}{ PROSENTASE LABA 15\% } & $\mathrm{Rp}$ & $55,553.59$ \\
\hline \multicolumn{5}{|c|}{ TARIF JASA RAWAT INAP KELAS III } & $\mathbf{R p}$ & $425,910.87$ \\
\hline
\end{tabular}


Berdasarkan hasil penghitungan tarif jasa rawat inap pada kelas III dengan menggunakan activity based costing system (ABCS) di rumah sakit Paru Pamekasan dihasilkan tarif jasa Rp.425.910,87 dengan keuntungan 15\%. Hal ini lebih besar Rp.210.910,87 dari tarif jasa rawat inap yang diterapkan oleh RS Paru Pamekasan sebesar Rp.215.000. Adanya selisih tarif tersebut disebabkan RS Paru Pamekasan masih menggunakan perkiraan biaya (akuntansi tradisional) sehingga biaya-biaya yang ditimbulkan oleh aktivitas pasien selama dirawat.
Penanggungan tarif biaya rawat inap kepada pasien terdapat biaya yang dikenakan langsung dan tarif bagi pasien yang tergolong tidak mampu dengan caramenunjukkan kartu JAMKESMAS. Besarnya tarif yang dikenakan dalam pengklaimnya terhadap pemerintah disesuaikan dengan tarif yang telah ditentukan oleh pihak rumah sakit Paru Pamekasan.

Tabel 13

Perbandingan Tarif Jasa Rawat Inap ABCS

dengan Tarif yang Berlaku Di Rumah Sakit Paru Pamekasan

\begin{tabular}{|l|rr|rr|rr|}
\hline \multicolumn{1}{|c|}{ Tipe Kamar } & \multicolumn{2}{|c|}{ Tarif ABCS } & \multicolumn{2}{c|}{ Tarif yang berlaku } & \multicolumn{2}{c|}{ Selisih } \\
\hline VIP & $\mathrm{Rp}$ & $604,320.42$ & $\mathrm{Rp}$ & $590,000.00$ & $\mathrm{Rp}$ & $14,320.42$ \\
\hline Kelas I & $\mathrm{Rp}$ & $485,909.18$ & $\mathrm{Rp}$ & $445,000.00$ & $\mathrm{Rp}$ & $40,909.18$ \\
\hline Kelas II & $\mathrm{Rp}$ & $360,095.44$ & $\mathrm{Rp}$ & $335,000.00$ & $\mathrm{Rp}$ & $25,095.44$ \\
\hline Kelas III & $\mathrm{Rp}$ & $425,910.87$ & $\mathrm{Rp}$ & $215,000.00$ & $\mathrm{Rp}$ & $210,910.87$ \\
\hline
\end{tabular}


Perbandingan yang terjadi antara tarif jasa rawat inap menggunakan metode activity based costing system dengan tarif yang berlaku di rumah sakit disebabkan oleh cost driver pada masing-masing tipe kamar sehingga mampu mengalokasikan biaya aktivitas ke setiap kamar secara tepat berdasarkan konsumsi masing-masing produk berdasarkan aktivitas.

\section{KESIMPULAN}

Berdasarkan hasil penelitian dapat disimpulkan bahwa perhitungan tarif jasa rawat inap dengan menggunakan metode Activity Based Costing System memberikan hasil yang lebih tinggi dibandingkan dengan tarif yang diberlakukan oleh RS Paru Pamekasan.Perbedaan yang terjadi disebabkan karena pembebanan biaya overhead pada masing-masing tipe kamar rawat inap dan produk lebih rinci dengan menggunakan driver.

\section{DAFTAR PUSTAKA}

Blocher, Edward J, Chen, Kung H dan Lin, Thomas W. 2000. Manajemen Biaya: dengan Tekanan Strategis. Jakarta: Salemba Empat.

Carter. K William. 2009. Akuntansi Biaya. Buku 1. Edisi Keempat Belas. Jakarta: Salemba Empat.

Gabriela. 2012. Penerapan Activity Based Costing Pada Tarif Jasa Rawat Inap Rumah Sakit Umum

\author{
Daerah di Makassar. Makasar: \\ Universitas Hasanuddin.
}

Hansen dan Mowen. 1999. Akuntansi Manajemen Jilid I. Jakarta: Erlangga.

Hidayat, Nurul et al. 2012. Penentuan Tarif Jasa Rawat Inap dengan Menggunakan Activity Based Costing System (ABCS) di Rumah Sakit Paru BP4 Pamekasan.

Mulyadi,dkk. 2003. Activity Based Cost System Informasi Biaya untuk Pengurangan Biaya. Yogyakarta:UPPAMP YKPN.

Rayburn Gayle. 1999. Akuntansi Biaya dengan Menggunakan Pendekatan Manajemen Biaya. Jakarta:

Penerbit Erlangga. 
